\title{
Examination of Brine Contamination Risk to Aquatic Resources from Petroleum Development in the Williston Basin
}

U.S. Geological Survey scientists and cooperating partners are examining the potential risk to aquatic resources (for example, wetlands, streams) by contamination from saline waters (brine) produced by petroleum development in the Williston Basin of Montana, North Dakota, and South Dakota. The primary goals of this study are to provide a science-based approach to assess potential risk of brine contamination to aquatic systems and to help focus limited monitoring and mitigation resources on the areas of greatest need. These goals will be accomplished through field investigations that quantify brine movement and risk assessments using remotely-sensed and other spatial datasets.

\section{Background and Problem}

The Williston Basin (fig. 1) has been a leading domestic oil and natural gas producing region for more than one-half a century (fig. 2), and there are ongoing efforts to develop oil and gas from deeper formations, such as the Bakken Formation, which is critical to meet our future energy needs. Estimates suggest that for older oil fields, at least 10 barrels ( 1 barrel $=42$ U.S. gallons) of brine (greater than 35,000 milligrams per liter dissolvedsolids concentration) are produced per barrel of extracted oil (Wanty, 1997), and brine from the Williston Basin has some of the highest levels of dissolved solids in the United States (Otton, 2006). These large volumes of brine have been primarily disposed through the years into deep geologic units by means of disposal wells. Historically, brine also was discharged directly into surface waters or earthen evaporation pits (McMillion, 1965; Gorman, 1999). Before regulations enacted in the 1970s, the evaporation pits were unlined and had great potential to leak, thereby contaminating nearby groundwater, surface water, and soil. Possible sources of brine contamination include leakage from unlined pits, transport pipelines, storage tanks, and tanker trucks.

In the United States, the Williston Basin and Bakken Formation cover 249,697 and 125,684 square kilometers $\left(\mathrm{km}^{2}\right)$, respectively. Of the United States part of the Prairie Pothole Region $\left(324,308 \mathrm{~km}^{2}\right)$, $78,240 \mathrm{~km}^{2}$ are within the Williston Basin or the Bakken Formation.

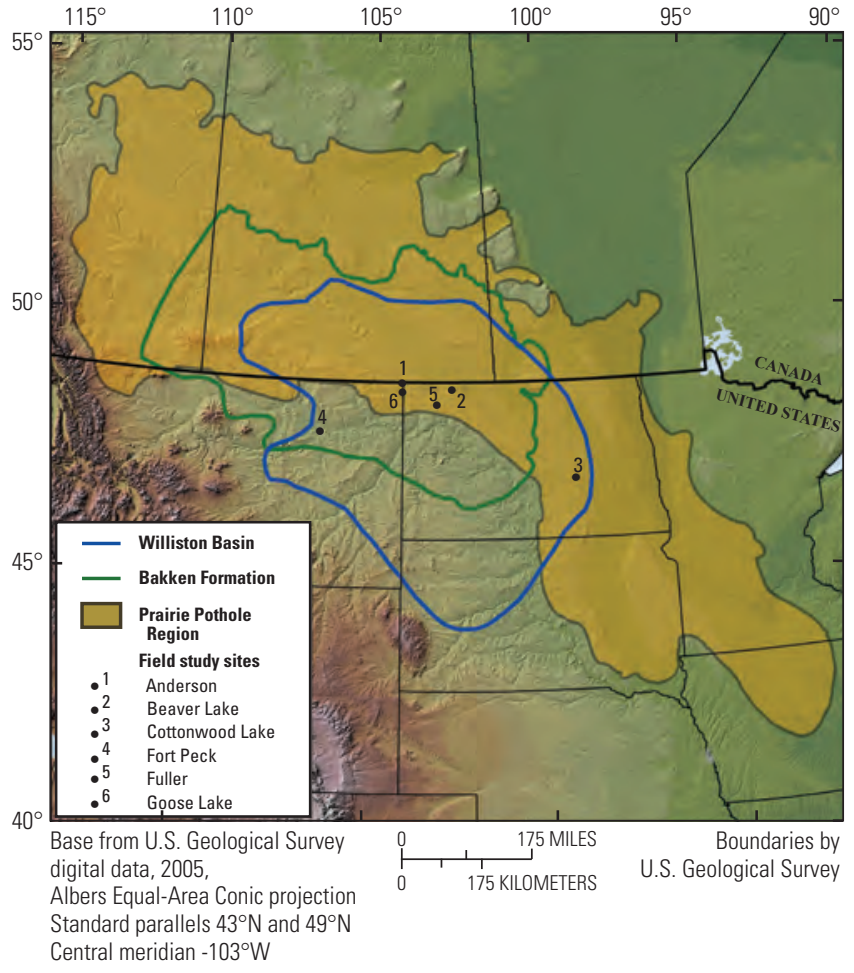

Figure 1. Location of the Williston Basin, Bakken Formation, and Prairie Pothole Region and field study sites.

A 2008 U.S. Geological Survey (USGS) assessment estimates that the Bakken Formation contains mean values of 3.65 billion barrels of technically recoverable oil, 1.85 trillion cubic feet of associated/dissolved natural gas, and 148 million barrels of liquid natural gas (Pollastro and others, 2008). Further, the Bakken Formation is one of the greatest potential gas reserves in the world (Durham, 2010), and government and industry personnel forecast significant increases in drilling and production in the coming years. As petroleum production increases, the potential environmental risk also increases. 


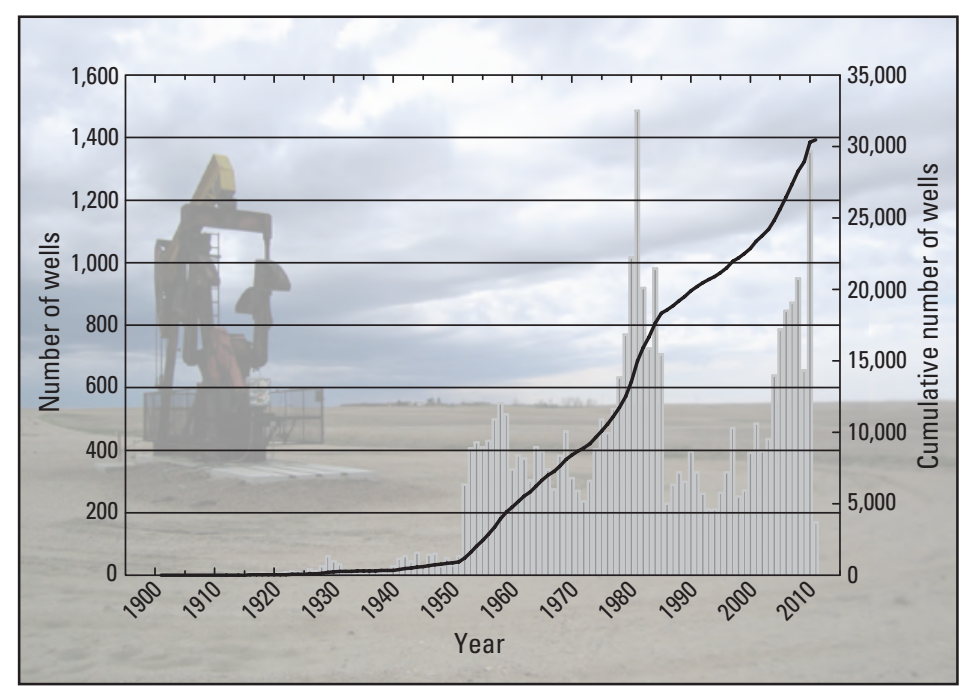

Figure 2. Number (bars) and cumulative number (line) of petroleum-related (for example, oil, gas, injection) wells permitted by year in the United States part of the Williston Basin (data were gathered as part of this study).

\section{Prairie Pothole Region}

The Prairie Pothole Region (PPR; fig. 1), an area characterized by abundant wetlands that are critical habitat for North America's migratory waterfowl and other wildlife, is superimposed over much of the Williston Basin. Approximately 50-90 percent of PPR wetlands have been drained and converted to cropland or otherwise altered by human activities (Dahl, 1990), at times causing unwanted effects such as excessive sedimentation or eutrophication. Accordingly, many government agencies and private conservation organizations are focused on restoring and protecting these important environments. Nonetheless, there are several environmental risks associated with petroleum production that often are overlooked by conservationists and managers of wetlands and other wildlife habitats. These threats include routine operational activities that lead to accidental chemical spills, effects associated with infrastructure construction, use of unlined reserve pits during drilling, and contamination by release of co-produced fluids. The addition of brine or other chemicals to surface waters and near-surface groundwater raises salinity levels and alters the natural composition (Reiten and Tischmak, 1993). These changes in water quality negatively affect the plant, invertebrate, and amphibian communities that make PPR wetlands so valuable to wildlife. Brine contamination also can make the water unsuitable for domestic livestock, which often rely on natural wetlands and streams or manmade stock ponds for drinking water. Lastly, increased salinity of shallow lakes could affect migrating birds, particularly if climate change produces less precipitation.

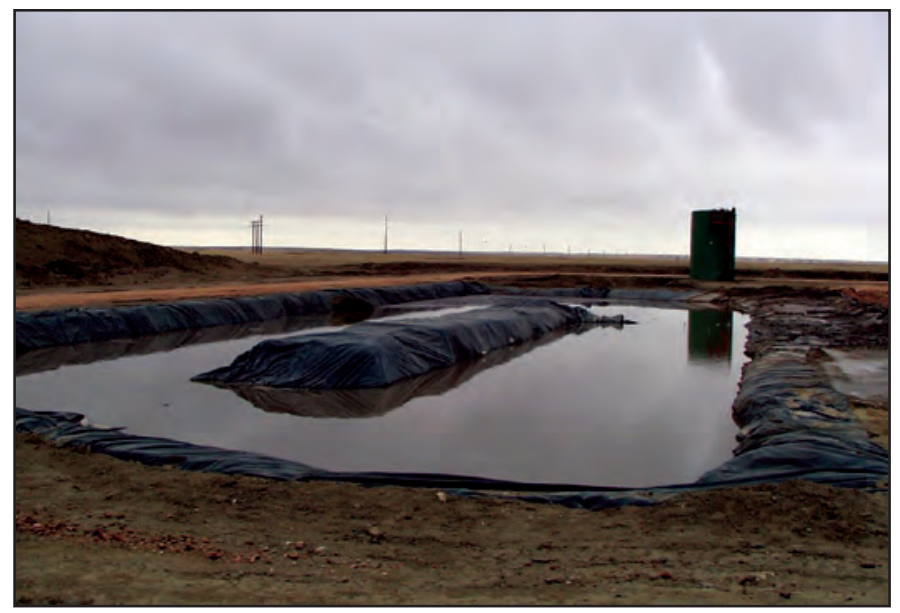

Brine storage pit.

Despite the potential critical environmental consequences from petroleum exploration and development, there is limited research in the Williston Basin and PPR pertaining to the effects of brine movement on wetlands and streams, and their associated biotic communities. Similarly, information regarding the spatial extent of wells and evaporation or reserve pits in relation to wetlands and streams is not readily available for the region. This lack of information hampers the ability of agencies such as the U.S. Fish and Wildlife Service (USFWS), which oversees large areas of land in the PPR, to evaluate the effects of petroleum development on wetlands and other aquatic resources.

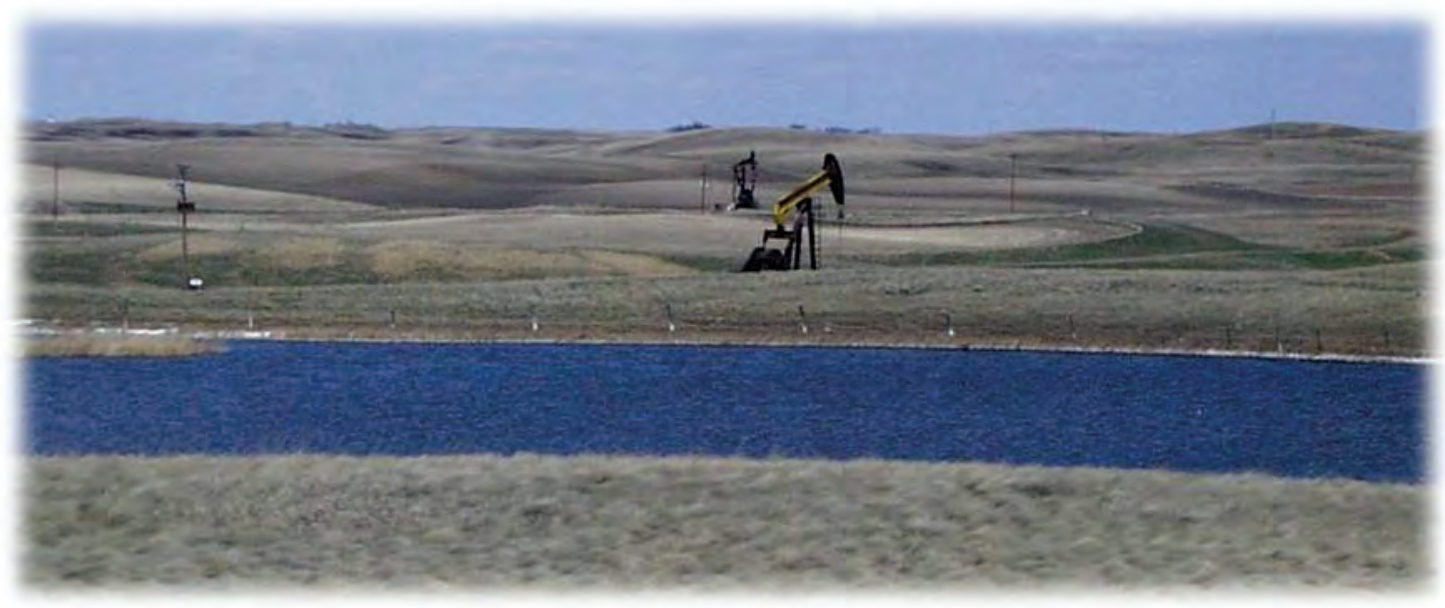

Wetland and oil well. 


\section{Past and Current Research}

During the 1980s the USGS, USFWS, and Montana Bureau of Mines and Geology (MBMG) began monitoring and mapping brine plumes in northeast Montana using electromagnetic geophysical survey methods along with data collected from groundwater wells (Payne and Reiten, 1991; Thamke and Craigg, 1997). Researchers from the MBMG and USFWS also developed an index based on the ratio of chloride concentration to specific conductance to identify brine-contaminated waters; results from the initial assessment indicated that about one-half of the evaluated sites were contaminated by brine associated with petroleum development (Reiten and Tischmak, 1993).

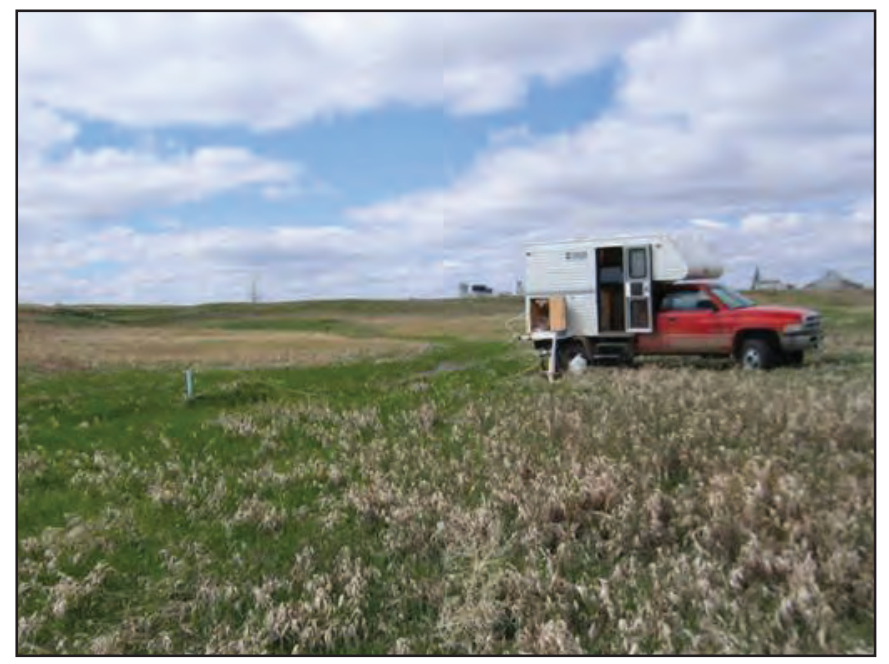

Collecting samples from groundwater wells below a storage-tank battery.

Currently (2011), an interdisciplinary team of USGS researchers is assessing the potential for petroleum production to affect wetlands and streams in the Williston Basin, with special focus on the PPR. This effort includes field studies and a spatial, geographic information system component. The information gathered for this study will assist land managers and agencies such as the USFWS to allocate limited monitoring and mitigation resources to areas with the greatest potential risk and to assess the threat posed to aquatic resources from brine contamination.

The multidisciplinary team consists of biologists, geologists, and hydrologists from the U.S. Geological Survey, the U.S. Fish and Wildlife Service, and the Montana Bureau of Mines and Geology. Support also has been provided by numerous State and local agencies.

\section{Chemistry of surface and shallow groundwaters natural and produced waters}

- The dissolved solids of surface waters and shallow groundwaters in the study area typically are between 1,000 and 10,000 milligrams per liter

- Surface waters and shallow groundwaters are characterized by sodium $(\mathrm{Na})$, magnesium $(\mathrm{Mg})$, sulfate $\left(\mathrm{SO}_{4}\right)$, and bicarbonate $\left(\mathrm{HCO}_{3}\right)$

- The dissolved solids of brines from oil production in the study area often are much greater than surface waters and shallow groundwaters, ranging from 100,000 to greater than 380,000 milligrams per liter (Iampen and Rostron, 2000)

- Brine from oil production typically is enriched in $\mathrm{Na}$ and chloride $(\mathrm{Cl})$

\section{Spatial Evaluation}

Remotely-sensed and other spatial datasets are being developed or gathered as part of this study to depict the spatial distribution of petroleum-related wells, wetlands, and streams. Data being gathered include information pertaining to well location and type, drilling date, oil producing formations, land ownership, aquatic resources (National Wetlands Inventory, National Hydrography Dataset), geology (USGS geologic maps), and soils (Soil Survey Geographic Database). This information will be used to identify areas with the greatest potential for brine contamination by identifying locales (for example, Counties, Townships) with the greatest densities of wells and aquatic resources. Further, detailed spatial investigations focused on the PPR will be conducted to assess the general proximity of wells to aquatic resources and to evaluate the potential risk to USFWS lands from nearby petroleum development.

\section{Oil Field Investigations}

Field investigations were conducted during 2009 and 2010 at new and previously studied (Reiten and Tischmak, 1993) sites representing the three primary glacial deposits in the PPR: till, outwash, and lacustrine. Water-quality data were collected from surface waters and groundwater wells, and electromagnetic surveys (EM-31, EM-34, GEM2) were conducted to determine the magnitude and subsurface extent of brine contamination in the various geologic deposits. These data will be compared to results from previous studies (Reiten and Teschmak, 1993) to evaluate and quantify the rate and extent of brine movement in the various geologic settings. 


\section{Future Research}

Information collected during this study will be disseminated to researchers, resource managers, and other stakeholders with the goals of raising awareness and advancing science. The knowledge gained from this study will provide the foundation for the development of research projects or management tools to assess the effects of petroleum development on aquatic resources and their biotic communities.

\section{References Cited}

Dahl, T.E., 1990, Wetland losses in the United States 1780s to 1980s: Washington, D.C., U.S. Department of the Interior, Fish and Wildlife Service.

Durham, L.S., 2010, Bakken fractures yield the goods, Oil Shale Takes Turn in Spotlight: American Association of Petroleum Geologists Explorer, v. 31, p. 34-36, accessed February 1, 2011, at http://www.aapg.org/explorer/2010/10oct/ bakken1010.cfm.

Gorman, H.S., 1999, Efficiency, environmental quality, and oil field brines: the success and failure of pollution control by self-regulation: Business History Review, v. 73, p. 601-640.

Iampen, H.T., and Rostron, B.J., 2000, Hydrogeochemistry of pre-Mississippian brines, Williston Basin, Canada-USA: Journal of Geochemical Exploration, v. 69-70, p. 29-35.

McMillion, L.G., 1965, Hydrologic aspects of disposal of oilfield brines in Texas: Ground Water, v. 3, p. 36-42.
Otton, J.K., 2006, Environmental aspects of produced-water salt releases in onshore and estuarine petroleum-producing areas of the United States-A bibliography: Reston, Va., U.S. Geological Survey Open-File Report 2006-1154, 223 p.

Payne, S.M., and Reiten, J.C., 1991, Impacts of oil field wastes on soil and ground water in Richland County, Montana, Part 3-Hydrogeologic conditions and ground-water quality at an oil well reserve pit: Montana Bureau of Mines and Geology Open-File Report 237C, 120 p.

Pollastro, R.M., Cook, T.A., Roberts, L.N.R., Schenk, C.J., Lewan, M.D., Anna, L.O., Gaswirth, S.B., Lillis, P.G., Klett, T.R., and Charpentier, R.R., 2008, Assessment of undiscovered oil resources in the Devonian-Mississippian Bakken Formation, Williston Basin Province, Montana and North Dakota, 2008: U.S. Geological Survey Fact Sheet 2008-3021, 2 p., accessed February 1, 2011, at http://pubs. usgs.gov/fs/2008/3021/.

Reiten, J.C., and Tischmak, T., 1993, Appraisal of oil field brine contamination in shallow ground water and surface water, eastern Sheridan County, Montana: Billings, Mont., Montana Bureau of Mines and Geology Open-File Report 260, 300 p., 2 sheet(s).

Thamke, J.N., and Craigg, S.D., 1997, Saline-water contamination in Quaternary deposits and the Poplar River, East Poplar oil field, northeastern Montana: U.S. Geological Survey Water-Resources Investigations Report 97-4000, 37 p.

Wanty, R.B., 1997, USGS research on saline waters co-produced with energy resources: Denver, Colo., U.S. Geological Survey Fact Sheet 003-97.

\section{Produced by the Science Team for Energy in Prairie Pothole Environments (STEPPE):}

- Robert Gleason, U.S. Geological Survey, Northern Prairie Wildlife Research Center

- Tara Chesley-Preston, Private Contractor, Northern Rocky Mountain Science Center

- Todd Preston, U.S. Geological Survey, Northern Rocky Mountain Science Center

- Bruce Smith, U.S. Geological Survey, Crustal Geophysics and Geochemistry Science Center

- Brian Tangen, U.S. Geological Survey, Northern Prairie Wildlife Research Center

- Joanna Thamke, U.S. Geological Survey, Montana Water Science Center

- Detailed project information can be found at: http://steppe.cr.usgs.gov/

For more information concerning this publication contact:

Robert Gleason

USGS Northern Prairie Wildlife Research Center

8711 37th Street Southeast

Jamestown, North Dakota 58401

701-253-5546

Email:rgleason@usgs.gov

Or visit the Northern Prairie Wildlife Research Center Web site at:

http://www.npwrc.usgs.gov 